\title{
IMPACT OF FRICTION ON THE UNIAXIAL SOIL SAMPLE COMPRESSION PROCESS $^{1}$
}

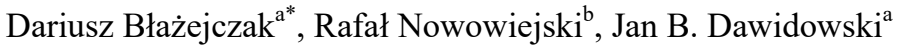 \\ ${ }^{a}$ Department of Construction and Usage of Technical Devices, West Pomeranian University \\ of Technology in Szczecin \\ ${ }^{b}$ Departemnt of Agrotechnical Systems Engineering West Pomeranian University of Technology in \\ Szczecin \\ ${ }^{*}$ Corresponding author: e-mail: dariusz.blazejczak@zut.edu.pl
}

\begin{tabular}{|c|c|}
\hline ARTICLE INFO & ABSTRACT \\
\hline $\begin{array}{l}\text { Article history: } \\
\text { Received: January } 2017 \\
\text { Received in the revised form: } \\
\text { February } 2017 \\
\text { Accepted: March } 2017\end{array}$ & $\begin{array}{l}\text { The objective of the research was to determine the impact of the } \\
\text { friction force between the cylinder wall and soil on the soil compac- } \\
\text { tion resistance in relation to the sample height and diameter of the } \\
\text { compaction plate. Samples with the diameter of }(D) 100 \mathrm{~mm} \text { and } \\
\text { heights }(H) \text { of } 30,50 \text { or } 100 \mathrm{~mm} \text { made of of soil material collected }\end{array}$ \\
\hline $\begin{array}{l}\text { Key words: } \\
\text { soil, } \\
\text { compaction resistance, } \\
\text { friction, } \\
\text { plate diameter, } \\
\text { sample height }\end{array}$ & $\begin{array}{l}\text { from subsoil of the selected plastic soils were used. The soil material } \\
\text { wasidentified by the following properties: the granulation type, densi- } \\
\text { ty of the solid phase, humus and calcium carbonate content, reaction, } \\
\text { plastic and liquid limit. Properties of the samples were described with } \\
\text { moisture, dry density of solid particles, porosity of aeration, plastic } \\
\text { degree and saturation. The samples were loaded with plates of varied } \\
\text { diameters }\left(d_{\mathrm{A}}: 20 ; 30 ; 50 ; 70 ; 80 ; 90 \text { and } 98 \mathrm{~mm}\right) \text { measuring at the same } \\
\text { time forces on the main plate }\left(F_{\mathrm{A}}\right) \text { and the bottom one }\left(F_{\mathrm{B}}\right) \text { with the } \\
\text { fixed diameter }\left(d_{\mathrm{B}}=98 \mathrm{~mm}\right) \text {. The registered relationships between the } \\
\text { forces } F_{\mathrm{A}} \text { and } F_{\mathrm{B}} \text { and plate sinkage (samples deformation) were used for } \\
\text { determination of the impact of external friction forces (between the } \\
\text { cylinder wall and soil) on the compression resistance of soils. It was } \\
\text { found out that the participation of the friction force in relation to the } \\
\text { height of samples and plate diameter varied from } 0 \text { to ca. } 70 \% \text {. It was } \\
\text { proved that one may avoid the impact of the plate diameter } d_{\mathrm{A}} \text { on the } \\
\text { measurement of force } F_{\mathrm{A}} \text {, when the relation } d_{\mathrm{A}} / D \text {, for samples with the } \\
\text { heights of } H 30 \text { and } H 50 \text {, is respectively within } 0.5 \leq d_{\mathrm{A}} / D<0.8 \text { and } \\
0.5 \leq d_{\mathrm{A}} / D<0.7 \text {. }\end{array}$ \\
\hline
\end{tabular}

\section{Introduction}

Excessive soil compaction by machines and tractors, which leads to unfavourable changes of soil properties, is one of the most important problems of modern agriculture (Krasowicz et al., 2011). Soil compaction increases when soil load by wheels exceeds the resistance to compaction, which can be defined with a pre-compaction stress. It is consid-

${ }^{1}$ This publication was written as a part of the project financed from the funds of the National Centre of Science (Agreement no. 7808/B/P01/2011/40) 
ered that knowledge on the pre-compaction stress value enables forecasting of soil loading with driving mechanisms, exceeding of which poses a threat of the increase of its compaction (Horn and Fleige, 2003). A utilitarian meaning of the pre-compaction stress causes that this parameter is the object of research in many centres in the world. Complexity of the soil environment and changes of its properties cause that no standard method of determination of this parameter has been developed yet (Błażejczak, 2010).

The past research did not give an explicit answer to the question what conditions are required to carry out the loading of soil samples during the studies on soil pre-compaction stress (Dawidowski et al., 2003; Śnieg et al., 2008; Błażejczak, 2009b; Mosaddeghi et al., 2007). Thus, an attempt was made to investigate the impact of the plate diameter on the value of the determined pre-compaction stress of soil (Błażejczak and Dawidowski 2016a; Błażejczak and Dawidowski, 2016b). The research, which was carried out, proves that the relation of the plate diameter $\left(d_{\mathrm{A}}\right)$ to the cylinder diameter $(D)$ should be within $0.5 \leq \mathrm{d}_{\mathrm{A}} / \mathrm{D} \leq$ 0.8 . It was also stated that the plate diameter $\left(d_{\mathrm{A}}\right)$ and sample height $(H)$ do not affect the measurement result when the relation $d_{\mathrm{A}} / D$ is within $0.5 \leq d_{\mathrm{A}} / D \leq 0.8$ and the ratio $D / H$ is 2 (Błażejczak and Dawidowski, 2017) and that it is possible to omit the condition $d_{\mathrm{A}} / D$, when soil is less-cohesive and its moisture degree is ca. 0.41-0.44. At the same time, the fact that generalization of the obtained results requires further research, which enable determination of the impact of forces related to the influence of the cylinder wall on the value of the calculated pre-compaction stress of soil, was emphasised.

\section{Objective, scope and methods of research}

The objective of the research was to determine the impact of the friction force between the cylinder wall and soil on its compaction resistance in relation to the sample height and diameter of the compaction plate. An attempt was made to determine the sample height at which the impact of the cylinder wall on the measured compaction resistance, used for calculation of the value of the pre-compaction stress of soil, disappears.

The research material came from the selected soil of Szczecin Lowlands from the territory of the following rural areas: Obojno $(\mathrm{Ob})$, Ostoja $(O s 1)$ and Nowy Przylep $(\mathrm{Np})$. Loose soil mass was collected from the layer located at the depth of 35 to $40 \mathrm{~cm}$ within the period of spring or fall field works.

A textural group was determined with Bouyoucosa-Casagrande's method in Prószyński's modification group acc. to PTG (2009) [Polish Society of Soil Science]. Density of the solid phase was determined with a pycnometer method and the humus content, soil reaction and calcium carbonate with respective methods: Tiurin's, electrometric and Scheibler's method. The plastic limit was measured with the rolling method and the liquid limit with the use of Cassagrande's apparatus.

Model samples were made (formed) of the wet material, sieved through the sieve with $6 \mathrm{~mm}$ diameter compacted uniaxial (fig. 1a) in steel rings (cylinders) with the internal diameter $(D)$ of $100 \mathrm{~mm}$ and heights $(H)$ of: 30,50 or $100 \mathrm{~mm}$. Mass of the soil material used for filling a cylinder was selected in a way that enabled obtaining the density of the samples with the dry density of solid particles determined in these soils during previous field research (Błażejczak et al., 2010). However, in relation to the height of the samples, the soil material mass was compacted as a one layer $(H 30)$ or divided into subsequently compacted 
Impact of friction...

$2(H 50)$ or $3(H 100)$ layers. It aimed at obtaining samples with a uniform distribution of density in their entire volume. The following were calculated in samples: water moisture content and dry density of solid particles, porosity of aeration, plastic and moisture degree. Moreover, the ratio of moisture to the moisture corresponding to the plastic limit of the investigated soils was calculated.

The samples were subjected to secondary loading (Fig. 1b) with the use of the testing machine, with plates with varied diameters $\left(d_{A}\right)$ measuring at the same time the force on the bottom plate with a constant diameter $\left(d_{\mathrm{B}}\right)$. Previous studies were taken into consideration $d_{\mathrm{A}}$ for determination of the number of iterations (three) (Błażejczak and Dawidowski, 2016b). Samples were loaded with the plates with diameters $d_{\mathrm{A}}: 20 ; 30 ; 50 ; 70 ; 80 ; 90$ and $98 \mathrm{~mm}$. The registered changes of forces $F_{\mathrm{A}}$ and $F_{\mathrm{B}}$ were used for calculation of the participation of soil friction force on the cylinder walls in the registered soil compaction resistance in the investigated range of diameter changes $d_{\mathrm{A}}$ of the plate and the height $H$ of the sample.

a)

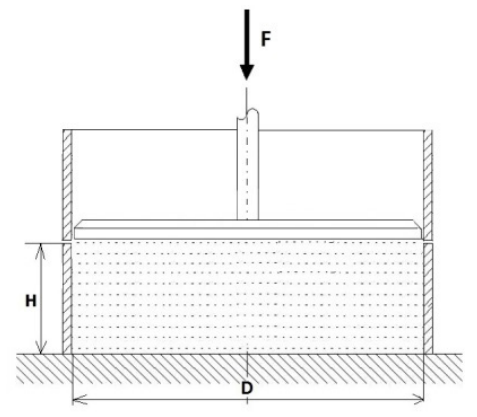

b)

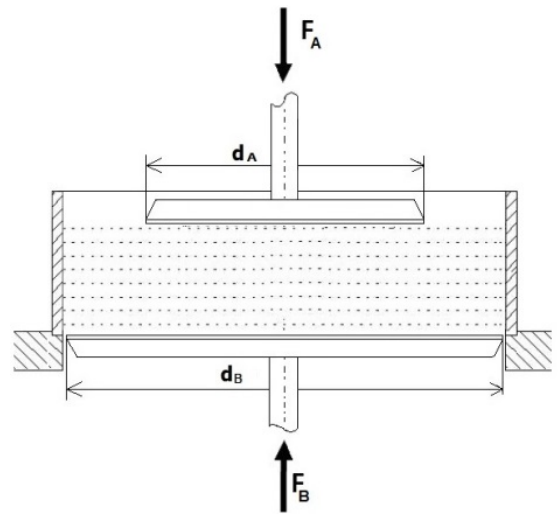

Figure 1. Methods of: $a$-samples formation, $b$-secondary samples deformation

\section{Results and their analysis}

Table 1 includes the results of measurement of the selected properties of the investigated soils. One may notice that they take varied values. Density of solid particles $(2.49-2.66$ $\left.\mathrm{g} \cdot \mathrm{cm}^{-3}\right)$ is typical for mineral soils. Soil reaction was within from weakly acid to neutral ( $\mathrm{pH}$ 5.10-6.84). The humus and calcium carbonate content, the values of plastic and liquid limit are respectively within: $0.60-3.77 \%, 0.00-2.50 \%, 18.4-28.0 \%$ and $27.6-47.9 \%$ Analysis of the values of the above mentioned properties enables a statement to be made that the research material came from soils which were exposed to permanent and strong deformation during their compaction in the state of a high moisture level (Krasowicz et al., 2011).

Table 2 includes the results of determination of properties of the samples. One may notice that their values within a given object were similar which means that they were uniform. Moisture of soils $(w)$ was lower than their plastic limit, and their liquidity index had 
Dariusz Błażejczak, Rafał Nowowiejski, Jan B. Dawidowski

negative values, which proves that the samples in the moment of deformation were compacted in the semid solid state (Wiłun, 2003).

Table 1.

Results of determination of own properties of the investigated soils

\begin{tabular}{|c|c|c|c|c|c|c|c|c|}
\hline \multirow{2}{*}{ Object } & \multirow{2}{*}{$\begin{array}{l}\text { Layer } \\
(\mathrm{cm})\end{array}$} & \multirow{2}{*}{$\begin{array}{c}\rho_{\mathrm{s}} \\
\left(\mathrm{g} \cdot \mathrm{cm}^{-3}\right)\end{array}$} & \multirow{2}{*}{$\begin{array}{l}\text { Reaction } \\
(\text { in } \mathrm{KCl}) \\
(\mathrm{pH})\end{array}$} & $Z_{\mathrm{pr}}$ & $\begin{array}{c}\text { Content } \\
\text { of } \mathrm{CaCO}_{3} \\
\end{array}$ & $w_{\mathrm{P}}$ & $w_{\mathrm{L}}$ & \multirow{2}{*}{$\begin{array}{c}\text { Textural group acc. } \\
\text { USDA } \\
\text { (PTG 2009) }\end{array}$} \\
\hline & & & & \multicolumn{2}{|r|}{$(\%)$} & \multicolumn{2}{|c|}{$\begin{array}{l}\text { moisture content } \\
(\% \mathrm{w} / \mathrm{w})\end{array}$} & \\
\hline$N P$ & $35-40$ & 2.46 & 6.34 & 2.02 & 2.5 & 21.3 & 31.2 & silt loam \\
\hline$O b$ & $35-40$ & 2.49 & 6.84 & 3.77 & 0.04 & 28.0 & 47.9 & loam \\
\hline Os1 & $35-40$ & 2.66 & 5.10 & 0.60 & 0.00 & 18.4 & 27.6 & loam \\
\hline
\end{tabular}

Symbols: $\rho_{\mathrm{s}}-$ specific density, $Z_{\mathrm{pr}}-$ humus content, $w_{\mathrm{P}}-$ plastic limit, $w_{\mathrm{L}}-$ liquid limit

Table 2.

Results of determination of samples properties

\begin{tabular}{lccccccc}
\hline Object & $\begin{array}{c}H \\
(\mathrm{~mm})\end{array}$ & $\begin{array}{c}\text { moisture content } \\
(\% \mathrm{w} / \mathrm{w})\end{array}$ & $\begin{array}{c}\rho_{\mathrm{d}} \\
\left(\mathrm{g} \cdot \mathrm{cm}^{-3}\right)\end{array}$ & $\begin{array}{c}n_{\mathrm{a}} \\
(\%)\end{array}$ & $\begin{array}{c}I_{\mathrm{L}} \\
(-)\end{array}$ & $\begin{array}{c}S_{\mathrm{r}} \\
(-)\end{array}$ & $\begin{array}{c}w / w_{\mathrm{p}} \\
(-)\end{array}$ \\
\hline \multirow{2}{*}{$N P$} & 30 & $19.1(0.6)$ & $1.46(0.05)$ & $12.5(2.3)$ & $-0.22(0.06)$ & $0.69(0.05)$ & $0.90(0.03)$ \\
& 50 & $19.1(0.1)$ & $1.50(0.01)$ & $10.1(0.3)$ & $-0.22(0.01)$ & $0.74(0.01)$ & $0.90(0.01)$ \\
& 100 & $19.0(0.4)$ & $1.48(0.00)$ & $11.5(0.5)$ & $-0.23(0.04)$ & $0.71(0.01)$ & $0.89(0.02)$ \\
\hline \multirow{3}{*}{ Ob } & 30 & $23.1(0.3)$ & $1.43(0.01)$ & $9.3(0.7)$ & $-0.25(0.02)$ & $0.76(0.01)$ & $0.82(0.01)$ \\
& 50 & $23.1(0.8)$ & $1.48(0.02)$ & $6.7(0.8)$ & $-0.24(0.04)$ & $0.84(0.02)$ & $0.83(0.03)$ \\
& 100 & $22.9(0.9)$ & $1.47(0.01)$ & $7.1(0.6)$ & $-0.26(0.04)$ & $0.83(0.02)$ & $0.82(0.03)$ \\
\hline \multirow{3}{*}{ Os1 } & 30 & $12.7(0.1)$ & $1.46(0.01)$ & $26.5(0.6)$ & $-0.62(0.01)$ & $0.41(0.01)$ & $0.69(0.00)$ \\
& 50 & $12.8(0.2)$ & $1.49(0.01)$ & $25.1(0.7)$ & $-0.61(0.02)$ & $0.43(0.01)$ & $0.70(0.01)$ \\
& 100 & $13.3(0.2)$ & $1.48(0.01)$ & $24.8(0.3)$ & $-0.56(0.03)$ & $0.44(0.01)$ & $0.72(0.01)$ \\
\hline
\end{tabular}

Symbols: $H$ - sample height, $w$ - water content, $\rho_{\mathrm{d}}$ - dry density of solid particles, $n_{\mathrm{a}}-$ porosity of aeration, $I_{\mathrm{L}}$ - plastic degree $S_{\mathrm{r}}$ - moisture degree; Notice: brackets include the value of standard deviation

The initial analysis of the obtained results shows that the plate diameter $\left(d_{\mathrm{A}}\right)$ influences the distribution of stresses in a sample. For plates, whose dimension $d_{\mathrm{A}}$ is close to the internal diameter of the cylinder $(D)$ an explicit difference in the registered values of forces $F_{\mathrm{A}}$ and $F_{\mathrm{B}}$ is noticeable. Exemplary courses of forces from the value of sample deformation for samples with the height of $H 30$ and selected plates were presented in figure 2. 
Impact of friction...
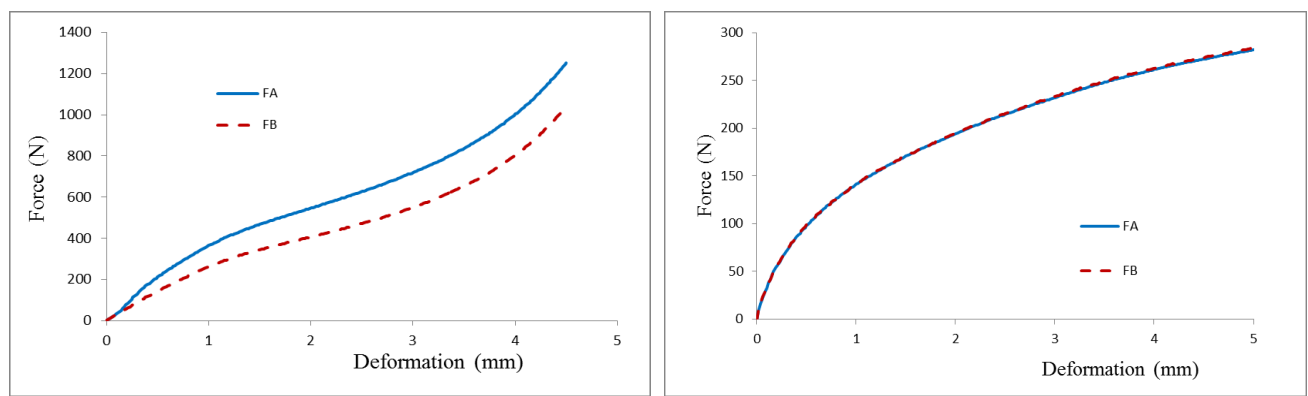

Figure 2. Exemplary courses of forces from the values of sample deformation for the samples with the height of H3O and diameters of compaction plates $d_{A}=98$ (diagram on the left) and $d_{A}=20 \mathrm{~mm}$ (diagram on the right)

The value of the difference between the forces $F_{\mathrm{A}}$ and $F_{\mathrm{B}}$ is also influenced, not only by the diameter of plate $d_{\mathrm{A}}$, but also by the sample height $(H)$. Figure 3 presents the exemplary courses of difference of forces $F_{\mathrm{A}}$ and $F_{\mathrm{B}}$ for samples with varied initial heights $(H)$ and diameters of plates $\left(d_{\mathrm{A}}\right)$.
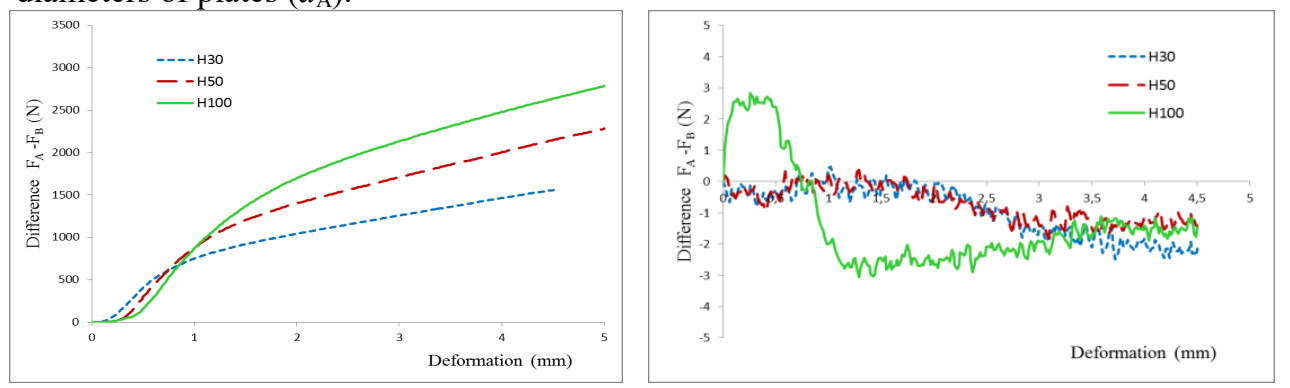

Figure 3. Exemplary courses of differences in forces $F_{A}$ and $F_{B}$ from the value of samples deformation with the heights of: H3O, H5O and H100; and diameters of compaction plates $d_{A}=98$ (diagram on the left) and $d_{A}=20 \mathrm{~mm}$ (diagram on the right)

Analysis of the results of previous research shows that (Błażejczak, 2009a) the value of the determined pre-compaction stress of soil is mainly affected by the course of the sample deformation process with regard to primary deformations which are from $1-2$ to $3-4 \mathrm{~mm}$. Thus, the values of forces registered within deformations between 2 and $4 \mathrm{~mm}$ were analysed. Average values of ratios $F_{\mathrm{B}} / F_{\mathrm{A}}$, for the investigated configurations of changes of the plate diameter $\left(d_{\mathrm{A}}\right)$ and the sample height $(H)$, were presented in table 3. Taking into consideration the spreads of the ratio values obtained for particular $d_{\mathrm{A}}$ and $H$ it was decided that the cylinder wall influences the registered course of force $F_{\mathrm{A}}$, when $F_{\mathrm{B}} / F_{\mathrm{A}} \leq 0.95$, which was written in bold. For $d_{\mathrm{A}}=d_{\mathrm{B}}$ (fig. $1 \mathrm{~b}$ ) results placed in table 3 are similar to those obtained by Koolen (1974), who determined the relation between the stresses ratio $\sigma_{\mathrm{B}} / \sigma_{\mathrm{A}}$ from the ratio $D / H$, which in this paper corresponds to $F_{\mathrm{B}} / F_{\mathrm{A}}$ from $D / H$. 
Dariusz Błażejczak, Rafał Nowowiejski, Jan B. Dawidowski

Table 3.

Average values of forces ratios $F_{B} / F_{A}$ calculated for the scope of samples deformation between 2 and $4 \mathrm{~mm}$ in relation to the plate diameter $\left(d_{A}\right)$ and the sample height $(H)$ for particular objects

\begin{tabular}{lrrrrrrrr}
\hline \multirow{2}{*}{ Object } & $H$ & \multicolumn{7}{c}{$d_{A}(\mathrm{~mm})$} \\
\cline { 2 - 9 } & & 20 & 30 & 50 & 70 & 80 & 90 & 98 \\
\cline { 2 - 9 }$N P$ & 30 & 1.00 & 1.00 & 1.00 & $\underline{0.98}$ & $\underline{\mathbf{0 . 9 2}}$ & $\mathbf{0 . 8 4}$ & $\mathbf{0 . 7 7}$ \\
& 50 & 1.00 & 1.00 & $\underline{0.97}$ & $\underline{\mathbf{0 . 8 6}}$ & $\mathbf{0 . 7 6}$ & $\mathbf{0 . 6 7}$ & $\mathbf{0 . 6 1}$ \\
& 100 & $\underline{0.99}$ & $\underline{\mathbf{0 . 9 3}}$ & $\mathbf{0 . 6 3}$ & $\mathbf{0 . 4 3}$ & $\mathbf{0 . 3 6}$ & $\mathbf{0 . 3 3}$ & $\mathbf{0 . 3 1}$ \\
\hline \multirow{3}{*}{$O b$} & 30 & 1.00 & 1.00 & 1.00 & $\underline{0.98}$ & $\underline{\mathbf{0 . 9 1}}$ & $\mathbf{0 . 8 2}$ & $\mathbf{0 . 7 6}$ \\
& 50 & 1.00 & 1.00 & $\underline{0.99}$ & $\underline{\mathbf{0 . 9 1}}$ & $\mathbf{0 . 8 1}$ & $\mathbf{0 . 6 9}$ & $\mathbf{0 . 6 3}$ \\
& 100 & $\underline{1.00}$ & $\underline{\mathbf{0 . 9 5}}$ & $\mathbf{0 . 8 8}$ & $\mathbf{0 . 5 4}$ & $\mathbf{0 . 4 6}$ & $\mathbf{0 . 4 0}$ & $\mathbf{0 . 3 4}$ \\
\hline \multirow{3}{*}{ Os 1} & 30 & 1.00 & 1.00 & 1.00 & $\underline{0.96}$ & $\underline{\mathbf{0 . 9 1}}$ & $\mathbf{0 . 8 2}$ & $\mathbf{0 . 7 9}$ \\
& 50 & 1.00 & $\underline{0.99}$ & $\underline{\mathbf{0 . 9 1}}$ & $\mathbf{0 . 7 9}$ & $\mathbf{0 . 7 4}$ & $\mathbf{0 . 6 6}$ & $\mathbf{0 . 6 4}$ \\
& 100 & $\underline{\mathbf{0 . 9 0}}$ & $\underline{\mathbf{0 . 5 5}}$ & $\mathbf{0 . 5 0}$ & $\mathbf{0 . 4 3}$ & $\mathbf{0 . 4 2}$ & $\mathbf{0 . 4 0}$ & $\mathbf{0 . 3 8}$ \\
\hline
\end{tabular}

Notice: values used for calculation of angle $F_{\mathrm{B}} / F_{\mathrm{A}}$ were underlined $\Theta$ (fig. 4)

a)

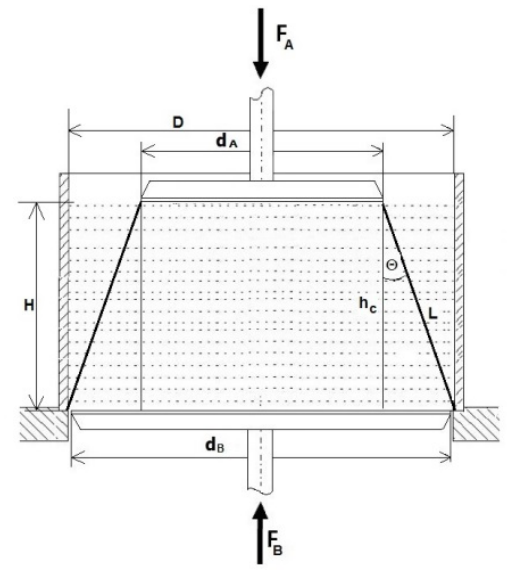

b)

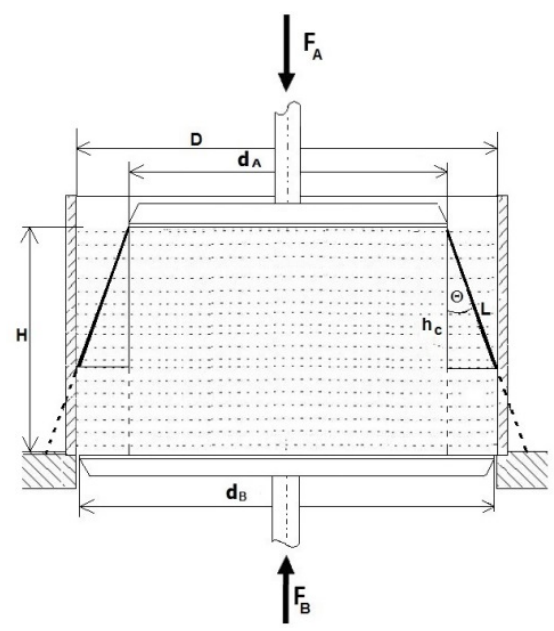

Figure 4. Method of determination of the impact of the cylinder wall on the soil compaction resistance: $a$-transition between no impact and occurance of the wall impact when $H \approx h_{c}$, $b$ - wall impact when $H>h_{c}$

Realization of the assumed objective required determination of an angle $(\Theta)$, which indicates distribution of stresses under the plate (fig. 4). Figure 4 presents an example, where load $F_{\mathrm{A}}$ placed on the upper surface is transmitted entirely to the bottom plate, which means 
Impact of friction...

$F_{\mathrm{A}}=F_{\mathrm{B}}$. Such state of balance of forces will take place also when the diameter of the plate will be decreasing. If we apply a plate with a diameter as in figure $4 \mathrm{~b}$ then the cylinder wall will affect the course of the compaction resistance - which was presented in bold in table 3 .

Table 4.

Calculated values of the angle $\Theta_{d}$ for particular values $d_{A}$ and $H$ and situation presented in figure $4 a$

\begin{tabular}{|c|c|c|c|c|c|c|c|c|}
\hline \multirow{3}{*}{ Object } & \multirow{3}{*}{$\begin{array}{c}H \\
(\mathrm{~mm})\end{array}$} & \multicolumn{7}{|c|}{$d_{A}(\mathrm{~mm})$} \\
\hline & & 20 & 30 & 50 & 70 & 80 & 90 & 98 \\
\hline & & \multicolumn{7}{|c|}{$\Theta_{\mathrm{d}}\left({ }^{\mathrm{o}}\right)$} \\
\hline \multirow{3}{*}{$N P$} & 30 & 53.1 & 49.4 & 39.8 & 26.6 & 18.4 & 9.5 & 1.9 \\
\hline & 50 & 38.7 & 35.0 & 26.6 & $\underline{16.7}$ & 11.3 & 5.7 & 1.1 \\
\hline & 100 & $\underline{21.8}$ & $\underline{19.3}$ & 14.0 & 8.5 & 5.7 & 2.9 & 0.6 \\
\hline \multirow{3}{*}{$O b$} & 30 & 53.1 & 49.4 & 39.8 & 26.6 & 18.4 & 9.5 & 1.9 \\
\hline & 50 & 38.7 & 35.0 & $\underline{26.6}$ & $\underline{16.7}$ & 11.3 & 5.7 & 1.1 \\
\hline & 100 & $\underline{21.8}$ & $\underline{19.3}$ & 14.0 & 8.5 & 5.7 & 2.9 & 0.6 \\
\hline \multirow{3}{*}{ Os1 } & 30 & 53.1 & 49.4 & 39.8 & $\underline{26.6}$ & $\underline{18.4}$ & 9.5 & 1.9 \\
\hline & 50 & 38.7 & $\underline{35.0}$ & $\underline{26.6}$ & 16.7 & 11.3 & 5.7 & 1.1 \\
\hline & 100 & $\underline{21.8}$ & $\underline{19.3}$ & 14.0 & 8.5 & 5.7 & 2.9 & 0.6 \\
\hline
\end{tabular}

Notice: values used for calculation of angle $\Theta_{d}$ were underlined $\Theta$ (fig. 4)

Angles $\Theta$ were searched for in stages. The first stage consisted in calculation of the angle value $\Theta_{\mathrm{d}}$, for the example presented in figure $4 \mathrm{a}$ acc. to the formula $\operatorname{arctg} \Theta_{\mathrm{d}}=(D$ $\left.d_{\mathrm{A}}\right) / 2 h_{\mathrm{c}}$, for particular values $d_{\mathrm{A}}$ and $H$ - results were presented in table 4 . In the second stage pairs of data $F_{\mathrm{B}} / F_{\mathrm{A}}$ and $\Theta_{\mathrm{d}}$ were prepared (underlined ones- table 3 and 4 ) for the transition state - between the stage of the cylinder walls impact and its loss - and then with the regression method the values of the angle were determined $\left(\Theta_{\mathrm{d}}\right)$ for $F_{\mathrm{B}} / F_{\mathrm{A}}=0.95$. In the third stage, the values of the angle $\Theta_{d}$ were averaged within particular objects obtaining finally the values which were searched for $\Theta$ for particular objects (Tab. 5). The obtained results are similar to the values assumed in geotechnology where for calculation of the distribution of stresses it is assumed that for compressive soils or less-compressive ones they get out of vertical respectively under the angles $22^{\circ}$ and $30^{\circ}$ (Wiłun, 2003).

The determined values of angles $\Theta$ were used for calculation, for respective diameters of plates $d_{\mathrm{A}}$, the maximum height of a sample $h_{\mathrm{c}}$ (table 5), the increase of which may cause the impact of the cylinder wall (when $D=100 \mathrm{~mm}$ ) on the course of the measured force value $F_{A}$, applied for determination of the pre-compaction stress of soil. Comparison of the calculated values $h_{\mathrm{c}}$ with the heights of used samples enables us to make a statement that in order to avoid the cylinder wall impact on the measured force values $F_{\text {A }}$ plates with the following diameters should be applied:

$-d_{\mathrm{A}}<80 \mathrm{~mm}$ for samples $H 30$,

- $d_{\mathrm{A}}<70 \mathrm{~mm}$ for samples $H 50$,

- $d_{\mathrm{A}}<20$ or $d_{\mathrm{A}}<30 \mathrm{~mm}$ (object $O b$ ) for samples $H 100$. 
Dariusz Błażejczak, Rafał Nowowiejski, Jan B. Dawidowski

Table 5.

Results of calculations $h_{c}$ at the determined angles $\Theta$ in relation to the plate diameter $d_{A}$ for a cylinder with the diameter of D100

\begin{tabular}{lcccccccc}
\hline & & \multicolumn{7}{c}{$d_{A}(\mathrm{~mm})$} \\
\cline { 3 - 8 } Object & $\Theta\left({ }^{\circ}\right)$ & 20 & 30 & 50 & 70 & 80 & 90 & 98 \\
\cline { 3 - 8 } & & \multicolumn{7}{c}{$h_{\mathrm{c}}(\mathrm{mm})$} \\
\hline$N P$ & 22.3 & 97.6 & 85.4 & 61.0 & 36.6 & 24.4 & 12.2 & 2.4 \\
$O b$ & 21.2 & 102.9 & 90.1 & 64.3 & 38.6 & 25.7 & 12.9 & 2.6 \\
Os 1 & 25.8 & 82.8 & 72.4 & 51.7 & 31.0 & 20.7 & 10.3 & 2.1 \\
\hline
\end{tabular}

Based on the analysis of results presented in table 5 , one may conclude that a correction of the previously obtained results, where it was stated that the plate diameter $\left(d_{\mathrm{A}}\right)$ and the sample heigth $(H)$ do not affect the measurement result with the use of cylinders with the height of $H 30$, when the relation of the plate diameter $\left(d_{\mathrm{A}}\right)$ to the cylinder diameter $(D)$ should be within $0.5 \leq d_{\mathrm{A}} / \mathrm{D} \leq 0.8$ (Błażejczak and Dawidowski, 2016b), should be carried out. Moreover, that the plate diameter $\left(d_{\mathrm{A}}\right)$ and the sample height $(H)$ do not affect the measurement result with the use of cylinders with the heights of $H 30, H 50$ and $H 100$, when the relation $d_{\mathrm{A}} / D$ is within $0.5 \leq d_{\mathrm{A}} / D \leq 0.8$ and the ratio $D / H$ equals 2 and that it is possible to omit the value $d_{\mathrm{A}} / D$ in a situation when soil is less cohesive and its moisture degree is 0.41-0.44 (Błażejczak and Dawidowski, 2017). After the correction was made, it should be assumed that the relation $d_{\mathrm{A}} / D$ should be within:

- $0.5 \leq d_{\mathrm{A}} / D<0.8$ for samples $H 30$,

- $0.5 \leq d_{\mathrm{A}} / D<0.7$ for samples $H 50$.

While, it is not recommended to apply samples with the height of $H 100$ with the use of a cylinder with diameter of $100 \mathrm{~mm}$. The fact that the plates with the diameter of $d_{\mathrm{A}}<50 \mathrm{~mm}$ are omitted in the correction, despite the fact that according to the results from table 5 they do not cause the impact of the cylinder wall on the registered compaction resistance of a sample, results from the higher spread of the determined pre-compaction stress values (Błażejczak and Dawidowski, 2016a, 2016b, 2017). It may be justified with the fact that along with the decrease of the plate diameter, the processes taking place in the zone of impact of its edges may have even bigger share in the soil compaction resistance.

Analysis of results placed in table 5 enable to answer the question why in the previous research with the use of cylinders with dimensions $D 100$ and $H 50$ and of a plate $d_{\mathrm{A}}=50$ $\mathrm{mm}$, models for forecasting pre-compaction stress of soil with a relatively small error in comparison to the forecast could have been obtained (Błażejczak, 2010). One may assume that one of the reasons could be a lack of the impact of the cylinder wall on the result of determination of the pre-compaction stress of soil since $H$ of the cylinder was lower than $h_{\mathrm{c}}$.

It should be added that in the discussion the impact of the sample base was omitted - in this paper the bottom plate with the diameter $d_{\mathrm{B}}$ - on the results of the soil compaction resistance measurment. It resulted from the fact that forming a compacted zone under the plate in the form of a cone requires a few-millimeter deformation of a sample (Earl, 1997), and in this paper the range of the sample deformation up to $4 \mathrm{~mm}$ was considered. The 
Impact of friction...

height of the compacted soil cone, which is formed under a foundation in the boundary condition, calculated in the initial stage of discussion according to Terzaghy's theory (Wiłun, 2003), did not exceed the height of the shortest cylinder used in the research, i.e. $30 \mathrm{~mm}$.

\section{Conclusions}

1. The value of the friction forces between soil and cylinder increases along with the increase of the cylinder height or the compaction plate diameters and depends non-lineary on the sample deformation.

2. Participation of the friction force between soil and cylinder with internal diameter of $100 \mathrm{~mm}$ in the compaction resistance $F_{\mathrm{A}}$ is, in relation to the model sample height and the plate diameter used for compaction between 0 and $70 \%$.

3. When using cylinders with a diameter $(D) 100 \mathrm{~mm}$, we may avoid the impact of the plate diameter $\left(d_{A}\right)$ on the determined value of the pre-compaction stress of plastic soils, caused by the friction force between soil and cylinder, when the relation $d_{A} / D$ for samples with the height of $H 30$ and $H 50$ is respectively within $0.5 \leq d_{\mathrm{A}} / D<0.8$ and $0.5 \leq$ $d_{\mathrm{A}} / D<0.7$.

4. It is not recommended to use a sample with the height which is the same as the diameter of a cylinder (D100), due to possible impact of the cylinder walls on the registered compaction resistance of a sample.

\section{References}

Błażejczak, D. (2009a). Analiza zależności naprężeń pierwotnych od wtórnych i stanu początkowego próbki gleby. Inżynieria Rolnicza, 1(110), 29-35.

Błażejczak, D. (2009b). Naprężenie graniczne próbek gleby o nienaruszonej strukturze w zależności od warunków ich odkształcania. Inżynieria Rolnicza, 5(114), 33-40.

Błażejczak, D. (2010). Prognozowanie naprężenia granicznego $w$ warstwie podornej gleb ugniatanych kołami pojazdów rolniczych. Wydawnictwo Uczelniane ZUT w Szczecinie. ISBN 978-837663-050-2.

Błażejczak, D., Dawidowski, J.B. (2016a). The Impact of the Plate Diameter on the Determined Value of the Pre-Compaction Stress of Samples made of Silt Soil. Agricultural Engineering. Vol. 2, 5-14.

Błażejczak, D., Dawidowski, J.B. (2016b). Impact of the Plate Diameter on the Determined Value of the Pre-Compaction Stress in soils with varied textural group. Agricultural Engineering, Vol. 3, 5-14.

Błażejczak, D., Dawidowski, J.B. (2017). Impact of Plate Diameter and Sample Height on the Determined Pre-compaction Value. Agricultural Engineering, Vol. 21, 19-28.

Dawidowski, J.B., Śnieg, M., Błażejczak, D., Morrison, Jr. J.E. (2003). Procedure on Indicated Values of Soil Precompaction Stress. Proceedings of 16th Triennial Conference of International Soil Tillage Organisation: Soil Management for Sustainability, 13-18 July 2003, The University of Queensland, Brisbane, Australia, 344-350.

Earl, R. (1997). Assessment of the behaviour of field soils during compression. Journal of Agricultural Engineering Research 68, 3, 147-157.

Horn, R., Fleige, H. (2003). A method for assesing the impact of load on mechanical stability and on physical properties of soils. Soil \& Tillage Research, 73, 89-99. 
Koolen, A.J. (1974). A method for soil compactibility determination. Journal of Agricultural Engineering Research, 19, 3, 271-278.

Krasowicz, S., Oleszek, W., Horabik, J., Dębicki, R., Jankowiak, J., Stuczyński, T., Jadczyszyn, J., (2011). Racjonalne gospodarowanie środowiskiem glebowym Polski. Polish Journal of Agrono$m y, 7,43-58$.

Mosaddeghi M.R., Koolen A.J., Hemmat A., Hajabbasi M.A., Lerink P. (2007). Comparisons of different procedures of pre-compaction stress determination on weakly structured soils. Journal of Terramechanics 44, 53-63.

Polskie Towarzystwo Gleboznawcze [Polish Society of Soil Science] (2009). Klasyfikacja uziarnienia gleb i utworów mineralnych - PTG 2008. Roczniki Gleboznawcze, 60(2), 5-16.

Śnieg, M., Błażejczak, D., Dawidowski, J.B., Tomaszewicz, T. (2008). Badanie podatności na zagęszczanie podornej warstwy czarnej ziemi gliniastej. Inżynieria Rolnicza, 5(103), 315-322.

Wiłun Z. (2003). Zarys geotechniki. WKiŁ, Warszawa, ISBN 83-206-1354-X.

\section{WPLYW TARCIA NA PRZEBIEG PROCESU JEDNOOSIOWEGO ŚCISKANIA PRÓBKI GLEBY}

Streszczenie. Celem badań było określenie wpływu sił tarcia pomiędzy ścianką cylindra a glebą na opór jej zagęszczania, w zależności od wysokości próbki i średnicy stempla zageszczającego. Stosowano próbki o średnicy $(D) 100 \mathrm{~mm}$ i wysokościach $(H)$ 30, 50 lub $100 \mathrm{~mm}$, wytwarzane z materiału glebowego pobranego z warstwy podornej wybranych gleb plastycznych. Materiał glebowy scharakteryzowano za pomocą: składu granulometrycznego, gęstości fazy stałej, zawartości próchnicy i węglanu wapnia, odczynu, granic plastyczności i płynności. Właściwości próbek opisano: wilgotnością, gęstością objętościową szkieletu, porowatością aeracji, stopniem plastyczności i stopniem wilgotności. Próbki obciążano stemplami o zróżnicowanych średnicach $\left(d_{\mathrm{A}}: 20 ; 30 ; 50 ; 70\right.$ 80; 90 i $98 \mathrm{~mm})$ mierząc jednocześnie siły na stemplu górnym $\left(F_{\mathrm{A}}\right)$ oraz dolnym $\left(F_{\mathrm{B}}\right)$ o stałej średnicy $\left(d_{\mathrm{B}}=98 \mathrm{~mm}\right)$. Zarejestrowane przebiegi sił $F_{\mathrm{A}}$ i $F_{\mathrm{B}}$ od odkształcenia próbek posłużyły do wyznaczenia wpływu sił tarcia zewnętrznego (pomiędzy ścianką cylindra a glebą) na opór ugniatania próbek. Stwierdzono, że udział sił tarcia, w zależności od wysokości próbki oraz średnicy stempla, wynosi od 0 do około $70 \%$. Wykazano, że można uniknąć wpływu średnicy stempla $d_{\mathrm{A}}$ na wynik pomiaru siły $F_{\mathrm{A}}$, gdy stosunek $d_{\mathrm{A}} / D$, dla próbek o wysokościach $H 30$ i $H 50$, zawiera się odpowiednio w przedziałach $0,5 \leq$ $d_{\mathrm{A}} / D<0,8$ i $0,5 \leq d_{\mathrm{A}} / D<0,7$.

Słowa kluczowe: gleba, opór zagęszczania, tarcie, średnica stempla, wysokość próbki 